\title{
The ERa membrane pool modulates the proliferation of pituitary tumours
}

\author{
Liliana del V Sosa1,*, Juan P Petiti1,*, Florencia Picech1, Sabrina Chumpen², Juan P Nicola³, Pablo Perez¹, \\ Ana De Paul', Javier Valdez-Taubas ${ }^{2}$, Silvina Gutierrez ${ }^{1}$ and Alicia I Torres ${ }^{1}$ \\ 1 Universidad Nacional de Córdoba, Facultad de Ciencias Médicas, Centro de Microscopía Electrónica - Consejo Nacional de Investigaciones Científicas \\ Técnicas (CONICET) Instituto de Investigaciones en Ciencias de la Salud, Córdoba, Argentina \\ 2Universidad Nacional de Córdoba, Facultad de Ciencias Químicas, CIQUIBIC-CONICET, Cordoba, Argentina \\ 3Universidad Nacional de Córdoba, Facultad de Ciencias Químicas, CIBICI-CONICET, Cordoba, Argentina
}

Correspondence should be addressed to A I Torres: atorres@cmefcm.uncor.edu

*(L d V Sosa and J P Petiti contributed equally to this work $)$

\begin{abstract}
The molecular mechanisms underlying the ER $\alpha$ nuclear/cytoplasmic pool that modulates pituitary cell proliferation have been widely described, but it is still not clear how ER $\alpha$ is targeted to the plasma membrane. The aim of this study was to analyse ER $\alpha$ palmitoylation and the plasma membrane $\mathrm{ER} \alpha(\mathrm{mER} \alpha)$ pool, and their participation in E2-triggered membrane-initiated signalling in normal and pituitary tumour cell growth. Cell cultures were prepared from anterior pituitaries of female Wistar rats and tumour GH3 cells, and treated with $10 \mathrm{nM}$ of oestradiol (E2). The basal expression of ER $\alpha$ was higher in tumour $\mathrm{GH} 3$ than in normal pituitary cells. Full-length palmitoylated ER $\alpha$ was observed in normal and pituitary tumour cells, demonstrating that E2 stimulation increased both, ER $\alpha$ in plasma membrane and ER $\alpha$ and caveolin-1 interaction after short-term treatment. In addition, the Dhhc7 and Dhhc21 palmitoylases were negatively regulated after sustained stimulation of E2 for $3 \mathrm{~h}$. Although the uptake of BrdU into the nucleus in normal pituitary cells was not modified by E2, a significant increase in the GH3 tumoural cell, as well as ERK1/2 activation, with this effect being mimicked by PPT, a selective antagonist of ER $\alpha$. These proliferative effects were blocked by $\mathrm{ICI} 182780$ and the global inhibitor of palmitoylation. These findings indicate that ER $\alpha$ palmitoylation modulated the $m E R \alpha$ pool and consequently the ERK1/2 pathway, thereby contributing to pituitary tumour cell proliferation. These results suggest that the plasma membrane ER $\alpha$ pool might be related to the proliferative behaviour of prolactinoma and may be a marker of pituitary tumour growth.
\end{abstract}

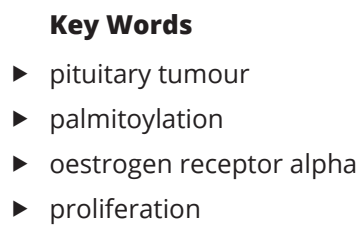

Journal of Endocrinology (2019) 240, 229-241

\section{Introduction}

Oestrogens act as important regulators of cell proliferation, cell survival and differentiation in a variety of organ systems and tissues and have been implicated in the aetiology of a variety of malignant cancers and benign tumours, such as pituitary adenomas (Spady et al. 1999). Most of the effects of oestrogen are mediated through its two receptors: oestrogen receptor alpha $(\mathrm{ER} \alpha)$ and beta
(ER $\beta)$ (Mitchner et al. 1998). ER $\alpha$ expression has been detected in both normal and tumour cells secreting PRL and gonadotropin (Friend et al. 1994), and at higher levels in macroadenomas than in microadenomas, and in non-invasive tumours than in invasive ones (Meitzen et al. 2013). It has been demonstrated that an oestrogen receptor antagonist inhibited pituitary tumour growth in 
a prolactinoma experimental model (Heaney et al. 2002), thereby making ER $\alpha$ a potential target for the treatment of high ERo-expressing pituitary adenomas (Gao et al. 2017).

In addition to the classic nuclear genomic action, oestrogens have been found to induce rapid effects within minutes of administration, which are mediated through a subpopulation of oestrogen receptors associated with the plasma membrane, a process usually termed 'membraneinitiated steroid signalling' (MISS), 'nongenomic' or 'extranuclear' effects (Watson et al. 2005, Ueda \& Karas 2013). Related to this, we previously demonstrated that $17 \beta$-oestradiol (E2) and FGF2 exerted a cooperative effect on lactotroph proliferation, principally by signalling initiated at the plasma membrane and mediated by the MEK/ERK1/2 pathway (Sosa et al. 2013).

The molecular mechanisms underlying the ER $\alpha$ nuclear/cytoplasmic pool modulating adenohypophyseal cell activity have been widely described. Although it is still not clear how ER $\alpha$ is targeted to the plasma membrane in normal and pituitary tumour cells, it has been reported that one of the requirements for ER to be located at the plasma membrane is the presence of a hydrophobic segment as part of the receptor structure (Marino et al. 2006, Morrill et al. 2015). A post-translational modification of ER $\alpha$ has been previously described, which includes the addition of a palmitate molecule (S-acylation, commonly called palmitoylation) in cysteine residues of the ligand-binding region of the gonadal steroid receptors (Acconcia et al. 2005, Pedram et al. 2007), by the palmitoyl-acyltransferases (PATs) DHHC7 and DHHC21 (Pedram et al. 2012). Adding lipid residues increases hydrophobicity, promoting steroid receptor translocation to the caveolae regions of the plasma membrane (Razandi et al. 2002, Peffer et al. 2014), with the different isoforms of caveolin (caveolin-1 and caveolin-2) being involved in this mechanism (Le Lay \& Kurzchalia 2005, Totta et al. 2015). ERo localisation in caveolae regions has been described in ovarian, prostate and breast tumour cells, suggesting an interaction between caveolin-1 and steroid receptors, which contributes to $\mathrm{mER} \alpha$ localisation as well as to the activation of extranuclear E2 signalling (Pedram et al. 2002, Acconcia et al. 2003, Park et al. 2009). However, the functional role of palmitoylation in normal and pituitary tumour cell proliferation and signalling has not yet been explored.

The results reported in the literature are related only to total ER $\alpha$ expression; thus, it is interesting to evaluate the $\mathrm{mER} \alpha$ expression in pituitary tumours. In the present study, we speculated that the mER $\alpha$ pool modulates cell proliferation in pituitary tumours. Thus, we tested the hypothesis that the increase of mER $\alpha$ mediated by palmitoylation triggers ERK1/2 phosphorylation and consequently pituitary tumour cell growth.

\section{Materials and methods}

\section{Cell cultures}

A pool of 3-month-old female Wistar rats, $(n=12)$, bred and housed at the Animal Research Facility of National University of Cordoba, was assigned to each culture taken at random cycle stages. The protocol for the dissociation of pituitary cells has been described previously (De Paul et al. 2011). The normal pituitary primary culture includes different type of cells, with the lactotroph (54.1\%) and somatotroph (21.8\%) being the two principal cell populations (data not shown). After 3-day culture, the cells were maintained in DMEM without phenol red and serum for $24 \mathrm{~h}$ before applying the treatments. The experiments were approved by the Institutional Animal Care Committee of the School of Medicine, University National of Cordoba.

The rat GH3 lactosomatotroph cell line is derived from rat prolactin-secreting pituitary tumours that synthesise both prolactin and growth hormone and has been used as a prolactinoma model (Boockfor et al. 1985, Chao et al. 2014). The cells were cultured in Ham's F-12 medium, supplemented with $2.5 \%$ foetal bovine serum and $15 \%$ horse serum (Gibco). The cell cultures with a confluence of $80 \%$ were maintained in DMEM without phenol red and serum for $24 \mathrm{~h}$ and then submitted to different experimental protocols

GH3 and primary adenohypophysis cells were stimulated for $30 \mathrm{~min}$ with E2 $(10 \mathrm{nM})$, a selective ER $\alpha$ agonist: $4,4^{\prime}, 4^{\prime \prime}$-(4-propyl-[1H]-pyrazole-1,3,5-tryl) Trisphenol (10nM, PPT) or epidermal growth factor (EGF) $(10 \mathrm{ng} / \mathrm{mL})$. For some experiments, the cells were preincubated with the global inhibitor of palmitoylation, 2-bromohexadecanoic acid $(2 \mathrm{BP} ; 10 \mu \mathrm{M})$ or ER pure antagonist: ICI 182780, for $30 \mathrm{~min}$.

\section{Determination of palmitoylated proteins by acyl-biotin exchange (ABE) assay}

The palmitoylated proteins were determined by the acylbiotin exchange (ABE) assay according to Wan et al. (2007) with modifications. The cells were extracted in cold lysis buffer (1.25\% Igepal CA-630, $1 \mathrm{mM}$ EDTA and protease and phosphatase inhibitors) and the proteins were 
concentrated by precipitation in chloroform-methanol and suspended in the SB buffer $(50 \mathrm{mM}$ Tris- $\mathrm{HCl}$, pH7.4, $5 \mathrm{mM}$ EDTA, 4\% SDS) with N-methylmaleimide (NEM-10mM). Next, $1 \mathrm{mM}$ NEM was added to the LB buffer (50mM Tris-HCl, pH7.4, $5 \mathrm{mM}$ EDTA, $150 \mathrm{mM}$ $\mathrm{NaCl}$ ), which was incubated overnight at $4^{\circ} \mathrm{C}$. The samples were divided into two equal portions $\mathrm{H}$ and Tris, with the $\mathrm{H}$ samples being diluted in $\mathrm{HB}$ buffer $(1 \mathrm{M}$ hydroxylamine, $150 \mathrm{mM} \mathrm{NaCl}, 0.2 \%$ Triton and $1 \mathrm{mM}$ HPDP-Biotin) and the Tris samples being diluted with the same buffer without hydroxylamine. Purification of the biotinylated proteins was completed by diluting with LB buffer containing streptavidin-agarose beads. Finally, the samples were re-suspended in $35 \mu \mathrm{L}$ LB containing $0.1 \%$ SDS, $0.2 \%$ TritonX-100 and $1 \% \beta$-mercaptoethanol and heated to $95^{\circ} \mathrm{C}$. The proteins were analysed by western blot using primary antibody anti-ER $\alpha$ (1/200; Santa Cruz Biotechnology).

The GH3 cell line was transfected with the plasmid encoding SX8-Cherry as a control of palmitoylated proteins. The expression plasmid $(1 \mu \mathrm{g})$ and the transfection reagent PEI $(2 \mu \mathrm{L}$, Sigma-Aldrich) were added for $2 \mathrm{~h}$ and then the GH3 cells were maintained in Ham's $\mathrm{F}-12$ an additional $24 \mathrm{~h}$.

\section{Analysis of cell-surface proteins by biotinylation}

The cell cultures were washed with PBS buffer and the cell-surface labelled proteins were purified using a cellsurface protein isolation kit (Pierce). The proteins from the supernatant and pellet fractions were analysed by western blot using the specific primary antibodies (Santa Cruz Biotechnology): anti-phosphorylated ERo (1/200), anti- $\beta$ actin (1/1000), anti-FGFR (1/200) and anti-EGFR (1/400).

\section{Immunoprecipitation}

The protein extract was subjected to immunoprecipitation using anti-ER $\alpha(5 \mu \mathrm{g} / \mathrm{mL})$. The immune complexes were adsorbed and precipitated using protein G-Sepharose beads (Sigma-Aldrich), washed and denatured by boiling for $5 \mathrm{~min}$ in sample buffer. The samples were analysed by western blot using anti-ER $\alpha(1 / 200)$ and anti-caveolin-1 (1/1000; Cell Signaling Technology).

\section{Preparation of cell lysates for western blotting analysis}

The samples were lysed in cold lysis buffer and the total homogenate $(50 \mu \mathrm{g})$ was separated using 12\%

(C) 2019 Society for Endocrinology Published by Bioscientifica Ltd. Printed in Great Britain polyacrylamide gel. The proteins on nitrocellulose membrane were blocked with $5 \%$ non-fat dried milk and $0.1 \%$ Tween 20 at RT and incubated overnight with primary antibodies 1/700 anti-diphosphorylated ERK1/2 (Sigma-Aldrich) and 1/1000 anti-total ERK1 (Santa Cruz Biotechnology, Inc). The blots were incubated with peroxidase-conjugated anti-rabbit (1/5000) or anti-mouse (1/2500 Jackson Immunoresearch Labs Inc) secondary antibodies and then revealed with ECL detection reagents (Inmun-Star HRP-Substrate Kits, Bio-Rad). Finally, the emitted light was captured by the C-DiGit Chemiluminescence Scanner (LI-COR Biosciences), and signals were quantified with ImageJ software.

\section{Gene expression analysis by qPCR}

qPCR analysis of cDNA was performed on an ABI Prism 7500 detection system (Applied Biosystem) using Power SYBR Green PCR Master Mix (Thermo Fisher Scientific) and the upper and lower gene-specific primer sequences used were DHHC-7 (NM_133394.1) 5'-GAGGATGGACC ACCACTGTC-3' and 5'-CATGATAGCCAGCTCATGC-3'; DHHC-21 (XM_006238345.1) 5'-GAGGATGGACCACCA CTGTC-3' and 5'-TCATGATAGCCAGCTCATGC-3'; DHHC-11 (NM_001039342.2) 5'-AACAACTTGACTTGGCC TACG-3' and 5'-GGCGAAAGAGTAGACAGCA-3' and $\beta$-actin (NM_031144) 5'-CCCACACTGTGCCCATCTA-3' and 5'-CGGAACCGCTCATTGCC-3'.

\section{Immunogold electron microscopy}

The subcellular localisation of the ER $\alpha$ and caveolin-1 in normal and GH3 cells was examined by ultrastructural immunocytochemical techniques applying previously standardised protocols (Petiti et al. 2015). Thin sections in the grids were incubated with anti-ER $\alpha(1 / 200)$ followed by anti-caveolin-1 (1/500) antibodies overnight at $4^{\circ} \mathrm{C}$. Then, the sections were incubated with anti-rabbit or antimouse secondary antibodies conjugated to $15 \mathrm{~nm}$ and $5 \mathrm{~nm}$ colloidal gold particles (1/30, Electron Microscopy Science) and examined in a Zeiss LEO 906-E transmission EM (TEM) (Zeiss).

\section{Immunofluorescence}

For $\operatorname{mER} \alpha$ staining, non-permeabilised live cells were incubated with ER $\alpha$ /Alexa Fluor 594 for $15 \mathrm{~min}$ at $4^{\circ} \mathrm{C}$ prior to fixation. The ER $\alpha /$ Alexa Fluor 594 complex was prepared by mixing an adequate dilution of ER $\alpha$ primary antibody and Alexa Fluor 594 secondary antibody for $30 \mathrm{~min}$ at $4^{\circ} \mathrm{C}$ before incubation with the cells. 
Images were obtained using a Confocal Laser Scanning Microscope FluoView FV 300 (Olympus) and processed using FV10-ASW 1.6 Viewer software.

\section{Correlative light and electron microscopy}

Correlative light and electron microscopy (CLEM) was carried out on ultrathin cryosections by applying the Tokuyasu technique as described by Oorschot (Oorschot et al. 2014). The cryosections were transferred on formvarcoated $100 \mu \mathrm{m}$ mesh nickel grids and incubated with antiER $\alpha$ antibody $1 / 50$ in 1\% BSA-PBS, followed by incubation with anti-rabbit Alexa-Fluor594 (1/300, Invitrogen) and DAPI (Sigma-Aldrich) for $1 \mathrm{~h}$ at $37^{\circ} \mathrm{C}$.

For fluorescence light microscopy (FLM), grids layered with a $200 \mathrm{~nm}$ coat of $2 \%$ methylcellulose were mounted with 50\% glycerol. For TEM observation, grids were unmounted, washed in milli-Q water and incubated in $0.4 \%$ uranyl acetate $1.8 \%$ methylcellulose. Fluorescence images were obtained using a Confocal Laser Scanning Microscope FluoView FV 1200 (Olympus) and, EM images using a Zeiss LEO 906-E TEM. The analysis was carried out with ImageJ software.

\section{Immunocytochemical detection of bromo-deoxyuridine uptake}

Cells at the DNA-synthesising stage were identified by immunocytochemical detection of BrdU. After $30 \mathrm{~min}$ of E2 stimulation, BrdU (100 nM) was added for an additional $24 \mathrm{~h}$. The cells attached to the coverslips were fixed in $4 \%$ formaldehyde in PBS for $2 \mathrm{~h}$ at room temperature and BrdU incorporation detection was performed as described by Ferraris (Ferraris et al. 2014). A total of 1000 cells were examined using a systematic process on each glass slide to establish the proportion of positive BrdU in the total cells.

\section{Data analysis}

A statistical analysis was carried out on three replicates measured from three independent cell cultures, with ANOVATukey using InfoStat software (Grupo InfoStat, Facultad de Ciencias Agropecuarias, UNC). The results are given as the means \pm S.E.M., and the significance levels were set at $P<0.05$.

\section{Results}

\section{ERa expression in normal and pituitary tumour cells}

First, we analysed the expression of total ER $\alpha$ in normal and pituitary tumour cells. The expression of ER $\alpha$ was higher

(c) 2019 Society for Endocrinology Published by Bioscientifica Ltd. Printed in Great Britain in tumour GH3 than in normal pituitary cells, and this did not change with the 30 min E2 treatment (Fig. 1A). Next, to determine whether ER $\alpha$ was palmitoylated in normal adenohypophysis and in GH3 pituitary tumour cells, the ABE assay was carried out followed by western blot. ER $\alpha$ full-length expression was observed as bands at around $66 \mathrm{kDa}$, and this protein was detected as palmitoylated in line $\mathrm{H}$ of $\mathrm{ABE}$, in normal adenohypophysis cells (Fig. 1B, top) and in the GH3 cell line (Fig. 1B, bottom). Furthermore, an additional ER $\alpha$-immunoreactive band around $50 \mathrm{kDa}$ was detected in the palmitoylated proteins line in GH3 cells, possibly corresponding to the splicing variant of ER $\alpha$. The SX8-Cher transfection in GH3 tumour cells showed a $70 \mathrm{kDa}$ band in line $\mathrm{H}$ of $\mathrm{ABE}$, confirming the presence of this palmitoylated protein (Fig. 1B, bottom).

\section{E2 regulates Dhhc7 and Dhhc21 palmitoylase expression}

Considering that the PATs are key to regulating the subcellular localisation of different ER $\alpha$ pools, Dhhc7 and Dhhc21 were evaluated by qPCR. As shown in Fig. 1C and $\mathrm{D}$, the Dhhc7 and Dhhc21 mRNA basal levels were higher in tumour than in normal cells. Then, we evaluated whether E2 was able to regulate the mRNA expression levels of these enzymes, with a significant decrease in Dhhc7 (Fig. 1E) and Dhhc21 (Fig. 1F) mRNA levels being observed in normal and GH3 cells stimulated with E2 for $3 \mathrm{~h}$ compared to control. However, this reduction was transient, as Dhhc7 and Dhhc21 mRNA levels returned to baseline values after 6 or $9 \mathrm{~h}$ of $\mathrm{E} 2$ treatment. The expression of Dhhc11 mRNA levels, used as a negative control, did not vary after E2 treatment either cell type (Fig. 1G).

\section{Membrane ERo expression is regulated by palmitoylation}

To explore whether palmitoylation could promote changes in mER $\alpha$ expression, pituitary cells were pretreated with 2BP, the global inhibitor of palmitoylation, and then stimulated with E2 for $30 \mathrm{~min}$. In unstimulated and nonpermeabilised pituitary cells, endogenous ER $\alpha$ specific immunostaining was observed at the plasma membrane in some normal pituitary and pituitary tumour cells. However, E2 treatment for 30 min increased ER $\alpha$ expression at the plasma membrane, which was more frequently observed in tumour cells and was reverted when the cells were pre-treated with 2BP 
A

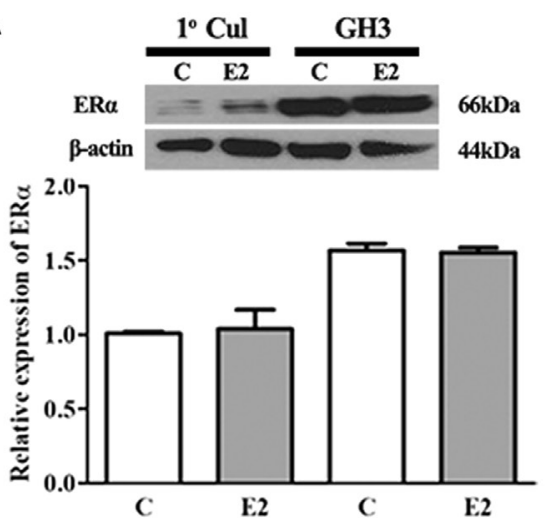

C

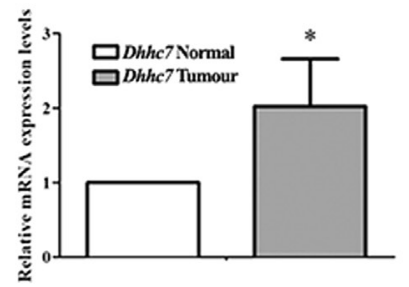

B

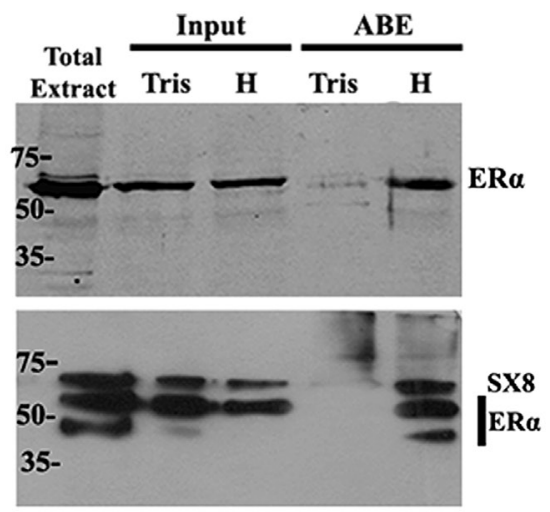

D

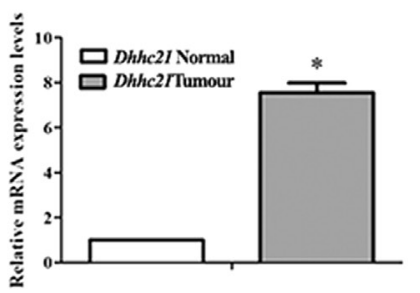

$\mathrm{E}$

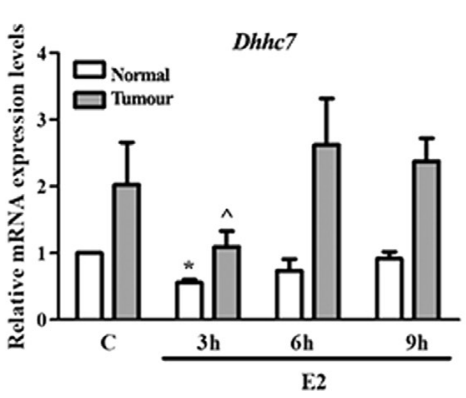

F
G
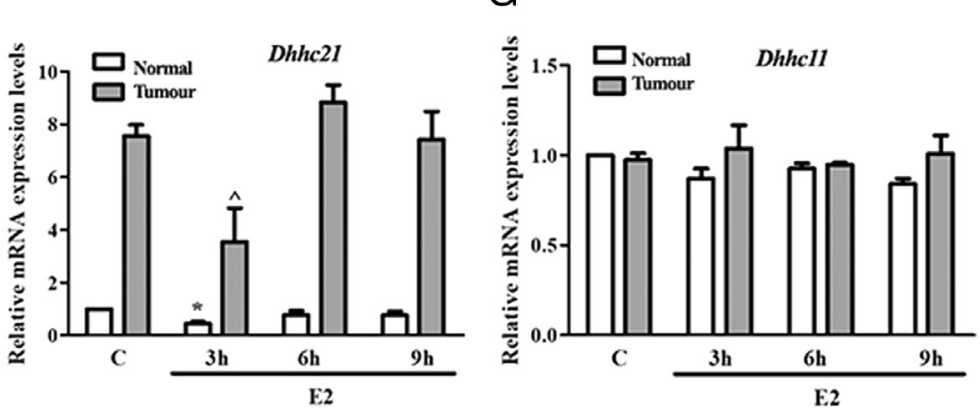

Figure 1

(A) Basal expression of total REa in normal and pituitary tumour cells and after E2 treatment for $30 \mathrm{~min}$. (B) Protein extracts from pituitary cells were tested for palmitoylated ERo following the ABE assay. Biotinylated proteins were purified, separated by SDS-PAGE and stained with anti-RE $\alpha$ antibody. ER $\alpha$ palmitoylation is prominent in protein extracts that were treated with hydroxylamine (H). In addition, in GH3-transfected SX8-Cher tumour cells, palmitoylated SX8 was used as a control of palmitoylated protein. The input in (A) and (B) was 10\% of total protein extract and Tris: pull-down without $\mathrm{H}$. Relative mRNA expression levels of Dhhc7 (C) and Dhhc21 (D) in normal pituitary and GH3 tumour cells. Dhhc7 (E), Dhhc21 (F) and Dhhc11 (G) mRNA expression levels after treatment with E2 $(10 \mathrm{nM})$ at 3, 6 and $9 \mathrm{~h}$. A significant decrease in the Dhhc7 and Dhhc21 mRNA levels was observed in normal and GH3 cells stimulated with E2 for $3 \mathrm{~h}$ compared to control. Expression levels were calculated by quantitative real-time PCR analysis. The $\beta$-actin gene was used as the internal reference gene and the $\Delta \Delta C T$ method was used for relative quantification and expressed as fold over control: ${ }^{*} P<0.05$ Dhhc7 vs $C$ and ${ }^{\wedge} P<0.05$ Dhhc21 vs $C$.

(Fig. 2A, B and C). We visualised the expression of ER $\alpha$ by CLEM (Fig. 2B and D), which enabled simultaneous observation of a given subcellular structure. In normal (Fig. 2B) and tumour GH3 (Fig. 2D) cells, the ER $\alpha$ was localised at the plasma membrane when the cells were treated with $\mathrm{E} 2$ for $30 \mathrm{~min}$.

The changes in $\mathrm{mER} \alpha$ expression in pituitary cells were analysed by cell-surface biotinylation. As shown in Fig. 2, western blot analysis revealed the presence of $\mathrm{ER} \alpha$ in the pellet fraction (containing the cellsurface biotinylated proteins) and in the supernatant fraction (with the intracellular unbiotinylated proteins).
In the pellet fraction, under baseline conditions, lower $\mathrm{ER} \alpha$ protein expression was observed in both normal (E) and tumour (F) cells, whereas E2 treatment for $30 \mathrm{~min}$ significantly increased $\mathrm{mER} \alpha$ expression, which was completely reversed by the $2 \mathrm{BP}$ pre-treatment.

\section{E2 induces ER $\alpha$ and caveolin-1 association}

As interaction between $\mathrm{ER} \alpha$ and caveolin-1 has been described in different tissues (Wang et al. 2011, Peffer et al. 2014), we evaluated whether E2 could promote any interaction in pituitary cells by using a 
A

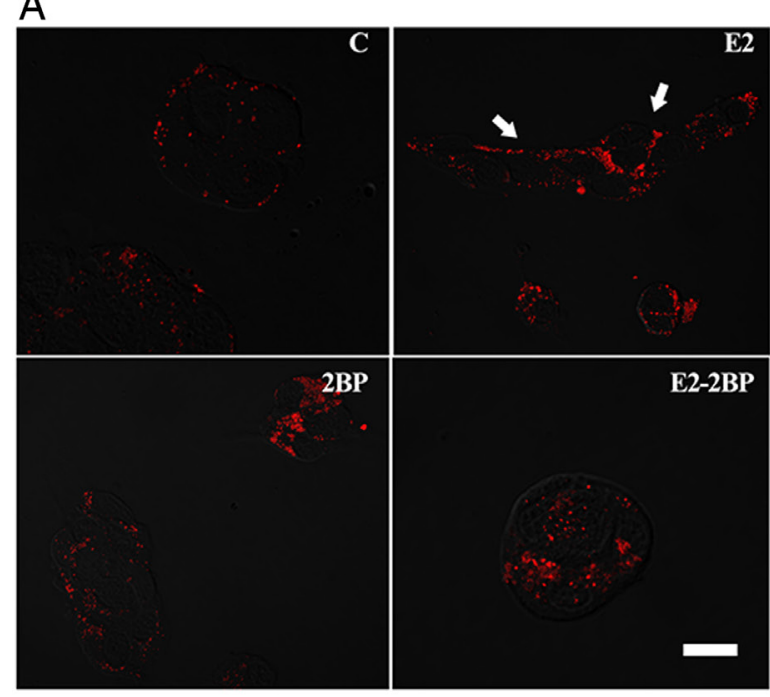

B

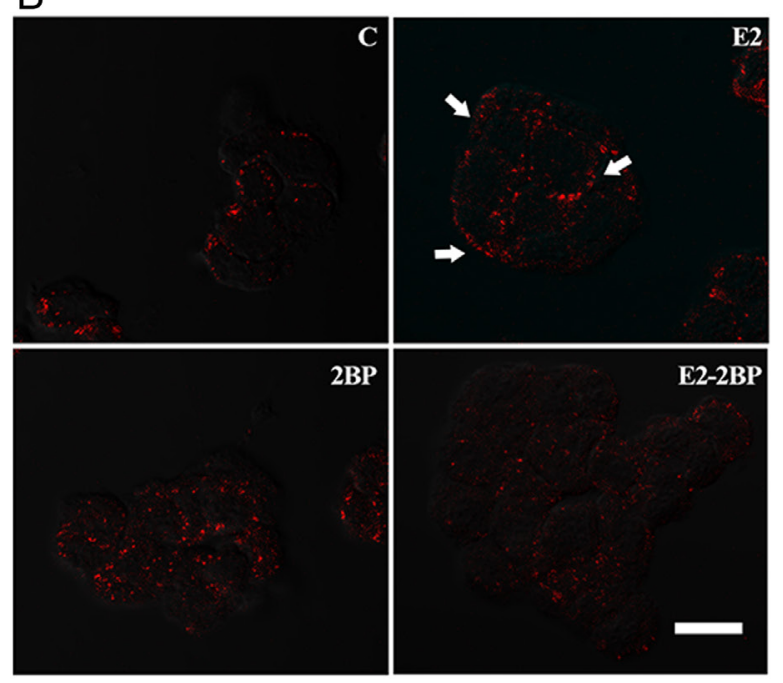

C

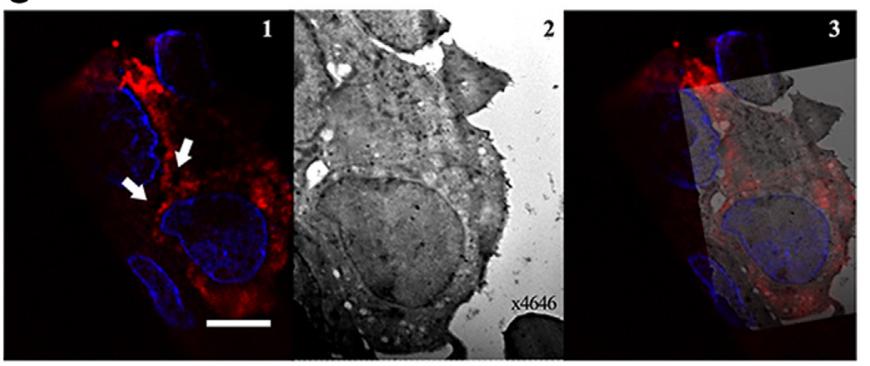

D
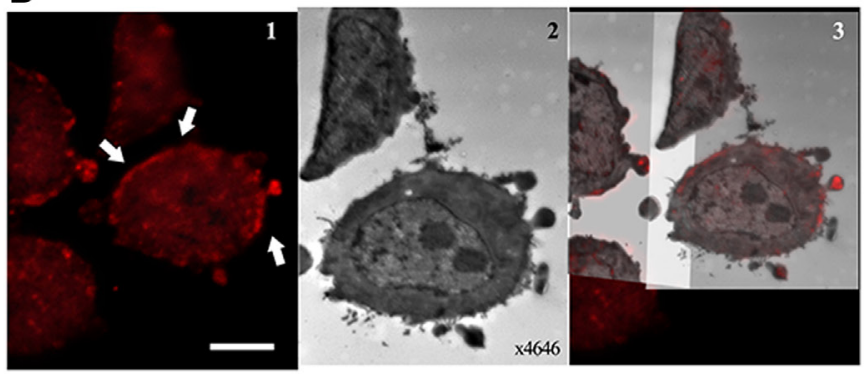

E
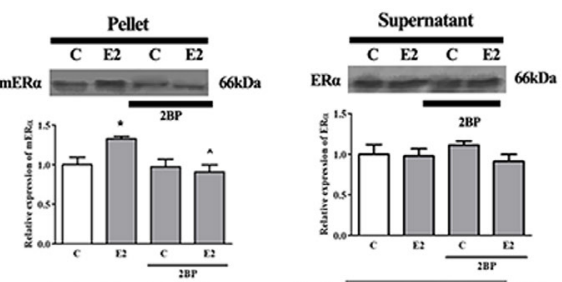

FGFR - - - 92kD

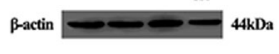

F
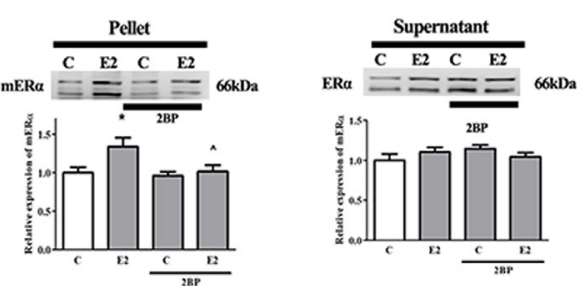

$\mathrm{EGFR}=\equiv=185 \mathrm{kDa}$

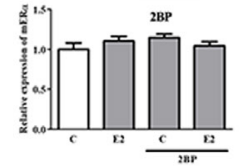

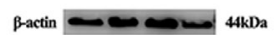

Figure 2

Cell-surface immunostaining of ER $\alpha$ in non-permiabilised normal (A) and tumour GH3 (B) cell cultures treated with E2 (10 nM) for 30 min with or without pre-treatment of 2BP. Microphotograph represent the merging of light transmitted and immunofluorescence field. CLEM of normal pituitary (C) and GH3 tumour (D) rat cell cultures were treated with E2. (1) Immunofluorescence labelling for ER $\alpha$, (2) TEM images for the whole section and (3) CLEM overlay of TEM on the corresponding FLM image. Arrows indicate ER $\alpha$ at plasma membrane. Bar: $10 \mu \mathrm{m}$. Biotinylation of cell-surface biotinylated proteins in normal pituitary and tumour GH3 rat cells. Surface membrane proteins were biotinylated in normal control (E) and tumour GH3 (F) pituitary cells or in cells treated with E2 $(10 \mathrm{nM})$ for $30 \mathrm{~min}$ with or without 2BP pre-incubation. Whole-cell lysates were subjected to avidin pull-down using streptavidin-agarose beads, and the recovered cell-surface biotinylated proteins (pellet) and intracellular unbiotinylated proteins (supernatant) were analysed by western blot and stained with anti-RE $\alpha$ antibody. In the pellet fraction, ER $\alpha$ expression showed an increase after E2 treatment but a decrease after pre-treatment with 2BP. The ER $\alpha$ expression did not change after treatment in the supernatant. The expression of the FGF and EGF receptors and $\beta$-actin confirmed equivalent total protein loading. Images correspond to a representative experiment from a total of three with similar results. Values are expressed as mean \pm S.E.M. ${ }^{*} P<0.05$ E2 vs $C$ and ${ }^{\wedge} P<0.05$ E2-2BP vs E2. A full colour version of this figure is available at https://doi.org/10.1530/JOE-18-0418.

co-immunoprecipitation assay. As shown in Fig. 3, in normal (A) and GH3 (C) unstimulated cells, a basal interaction was observed between both proteins, which was significantly increased by E2 treatment. Interestingly, 2BP treatment was able to reverse the E2-induced $\mathrm{ER} \alpha /$ caveolin-1 interaction, revealing similar expression levels as the controls.
In addition, we analysed the fine localisation of ER $\alpha$ with caveolin- 1 by means of TEM immunogold labelling in normal (B) and tumour GH3 (C) cells. As shown in Fig. 4B and $\mathrm{C}$, the immunoreactivity for $\mathrm{ER} \alpha$ ( $15 \mathrm{~nm}$ gold particle) was distributed in the cytoplasm and occasionally in the plasma membrane in normal and tumour control cells, whereas ER $\alpha$ localisation was frequently observed the 
plasma membrane, with caveolin-1 ( $5 \mathrm{~nm}$ gold particles) being close to each other in E2-treated cells.

\section{The involvement of palmitoylation and mER $\alpha$ in cell proliferation}

To analyse the contribution of mER $\alpha$ to cell proliferation, we determined the BrdU uptake into the nucleus of normal and pituitary tumour cells incubated with a palmitoylation inhibitor. The percentage of control normal BrdU-positive cells was $2.6 \%$, with no changes observed after the different treatments (Fig. 4A and B). However, in non-stimulated GH3 cells, the proliferation was around 30\%, showing a significant increase after E2 stimulation that was mimicked for PPT respect to control. The E2 effect was blocked partially by ICI 182780 and the global inhibitor of palmitoylation, 2BP (Fig. 4C and D).

Considering previous results from our laboratory concerning the involvement of the MEK/ERK1/2 and PI3K/AKT pathways in pituitary tumour cell proliferation (Petiti et al. 2010, 2015), we determined the phosphorylation of ERK1/2 and AKT in pituitary tumour cells. Figure 4E shows the significant increase in phosphorylated ERK1/2 after E2 and PPT treatments observed for $30 \mathrm{~min}$, which was blocked when the cells were pre-incubated with ICI 182780 or $2 \mathrm{BP}$, suggesting that ER $\alpha$ palmitoylation may be required to activate these kinases. The expression of phosphorylated AKT increased after E2 or PPT treatments for $30 \mathrm{~min}$, while pre-incubation with ICI 182780 or 2BP did not revert this activation, suggesting that AKT may contribute to the pituitary tumour proliferation induced by E2 in a mER $\alpha$-independent manner.

Additionally, we tested if the effect of the inhibitor of palmitoylation could affect the cell response to different growth stimulatory factors. With this aim, we analysed the proliferation and activation of ERK1/2 in GH3 cells stimulated with the EGF for $30 \mathrm{~min}$, in the presence or absence of the pre-incubation with 2BP. As shown in Fig. 4, the EGF treatment significantly increased the uptake of BrdU and ERK1/2 phosphorylation (Fig. 4F and $G$ ), effects that were not reverted when the cells were pre-treated with $2 \mathrm{BP}$, suggesting that the cell response to palmitoylation inhibitor is ER specific.

The above results indicate that the plasma membrane $\mathrm{ER} \alpha$ localisation mediated by ER $\alpha$ palmitoylation triggers ERK1/2 phosphorylation and consequently pituitary tumour cell growth.

\section{Discussion}

This study found that the subpopulation of ER $\alpha$ localised in the plasma membrane induced pituitary tumour proliferation by the $\mathrm{mRE} \alpha /$ cavelin1/ERK1/2 pathway. The E2 stimuli significantly increased mER $\alpha$ expression, ER $\alpha$ interaction with caveolin-1, ERK1/2 phosphorylation and finally led to pituitary tumour proliferation, which were partially reversed by the PAT inhibitor.

We previously identified the presence of ER $\alpha$ in the plasma membrane in normal pituitary cells
A

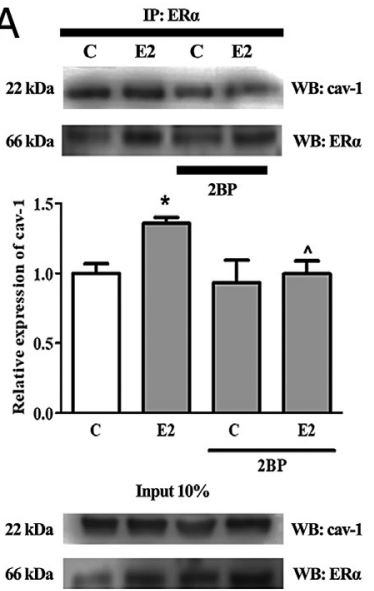

B

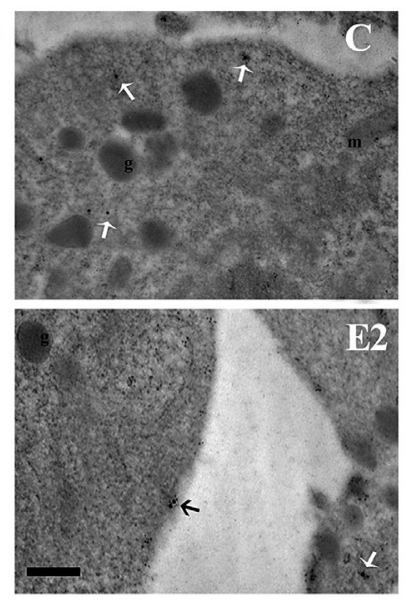

C

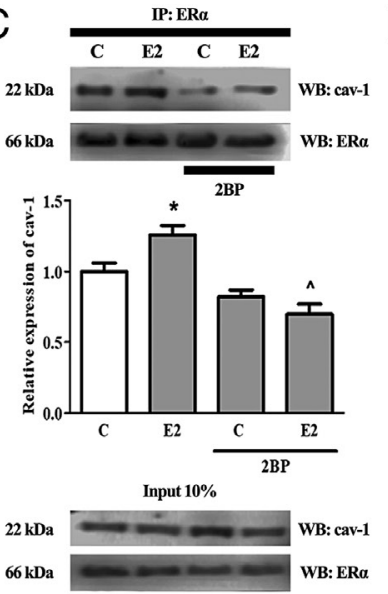

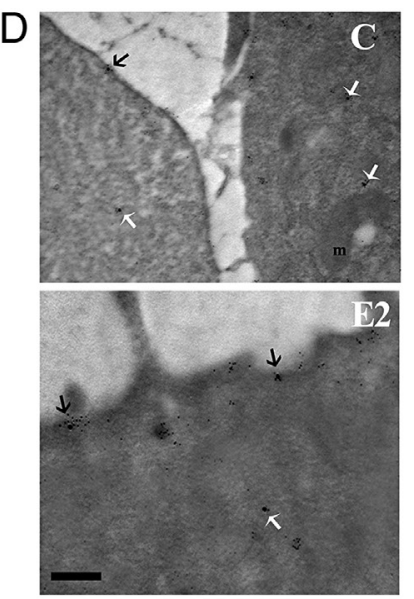

Figure 3

Association between ER $\alpha$ and caveolin 1. Normal pituitary (A) and tumour GH3 (C) rat cell cultures were treated with E2 (10 nM) for 30 min with or without pre-treatment of 2BP. The total cell extracts were used for immunoprecipitation (IP) using anti-ER $\alpha$ and the immunoprecipitates were then probed with anti-cav-1. ${ }^{*} P<0.01 \mathrm{E} 2$ vs $C$ and ${ }^{\wedge} P<0.05$ E2-2BP vs E2. In total anterior pituitary cell culture lysates, both antibodies recognised the antigens (input). Electron micrographs of normal pituitary (B) and tumour GH3 (D) with double immune-labelling of ER $\alpha$ ( $15 \mathrm{~nm}$ gold particle) and cav-1 ( $5 \mathrm{~nm}$ gold particle). The black arrows indicate the ERo-cav-1 adhered to the plasma membrane and the white arrows indicate the cytosolic ER $\alpha$. g, granule; bar: $100 \mathrm{~nm}$. 


\begin{tabular}{l|l|l|r|r|}
$\begin{array}{l}\text { Journal of } \\
\text { Endocrinology }\end{array}$ & L d V Sosa, J P Petiti et al. & $\begin{array}{l}\text { mERa pool contributes to } \\
\text { pituitary tumour growth }\end{array}$ & $\mathbf{2 4 0 : 2}$ & $\mathbf{2 3 6}$ \\
\hline
\end{tabular}
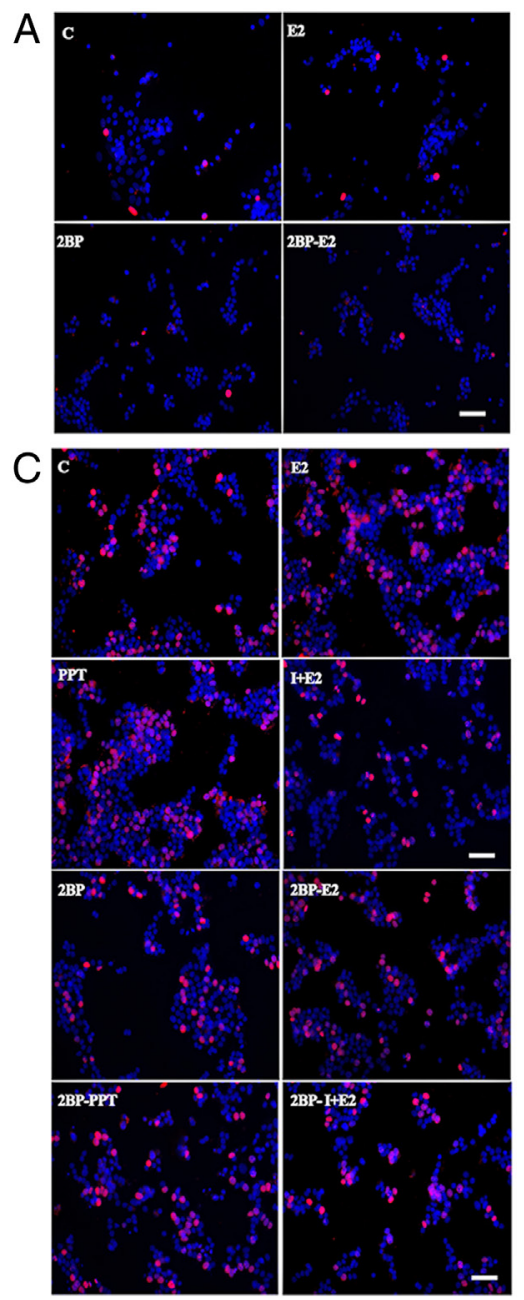

B
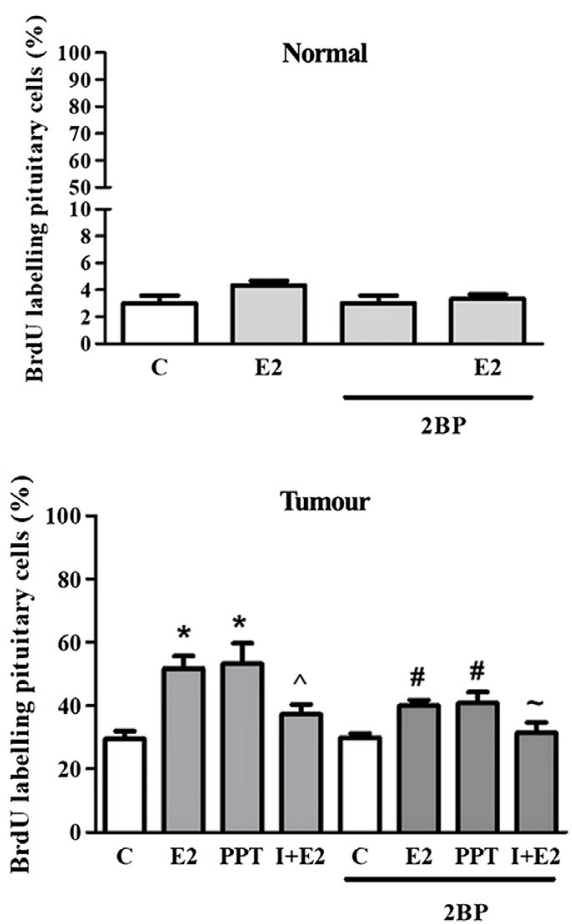

$\mathrm{F}$

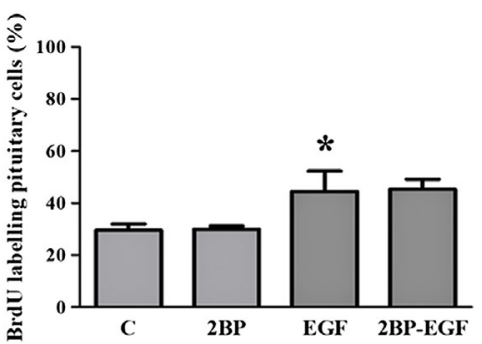

G

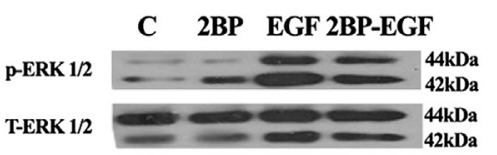

$E$

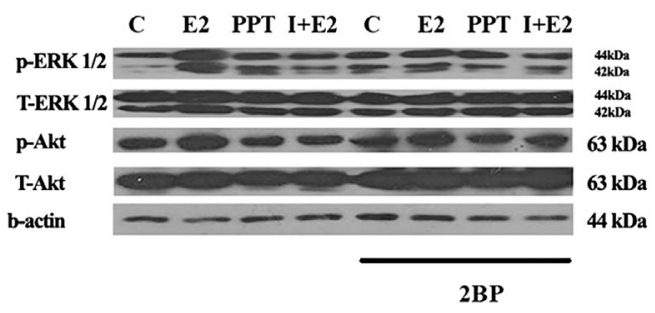

Figure 4

Representative micrographs of immunohistochemical staining for BrdU (red) and quantitative analysis in normal (A and B) and tumour GH3 (C and D) cell cultures. The cells were treated with E2 $(10 \mathrm{nM})$ or PPT (10 nM) for 30 min with or without pre-treatment with $2 \mathrm{BP}$ or ICl $182780(\mathrm{l}, 100 \mathrm{nM})$. BrdU was added for an additional $24 \mathrm{~h}$ and the data represent the proportion of positive BrdU cells in the total cells. Significant differences were found in GH3 cell proliferation: ${ }^{*} P<0.01$ E2 or PPT vs $C$ and ${ }^{\wedge} P<0.05$ I+ E2 vs E2. ${ }^{\#} P<0.05$ E2 or PPT vs E2 or PPT and $~ P<0.05$ 2BP-I+E2 vs E2. Bar: $100 \mu$ m. (E) Western blotting of ERK1/2 and Akt in total extract from tumour pituitaries treated with E2 $(10 \mathrm{nM})$ or PPT $(10 \mathrm{nM})$ for 30 min with or without pre-treatment of 2BP or ICI $182780(\mathrm{I}, 100 \mathrm{nM})$. The amount of protein levels was normalised by comparison with total ERK1/2 and AKT expression A representative panel of three independent experiments is shown. ( $F$ and $G$ ) Quantitative analysis of BrdU staining and western blotting of ERK1/2 in total extract from cells treated with EGF $(10 \mathrm{ng} / \mathrm{mL})$ for 30 min with or without pre-treatment with 2BP $(10 \mu \mathrm{M})$. Significant differences were found in GH3 cell proliferation: $\star P<0.01 \mathrm{EGF}$ vs $\mathrm{C}$, while that cell proliferation and ERK1/2 phosphorylation did not change with 2BP treatment. A full colour version of this figure is available at https://doi.org/10.1530/JOE-18-0418.

(Gutierrez et al. 2008), and it has also been demonstrated that E2 stimulates the translocation of endogenous ER $\alpha$ and the activation of the PKC $\alpha /$ ERK1/2 pathway (Gutierrez et al. 2012, Watson et al. 2012, Zarate et al. 2012), without any effect on cell proliferation (Sosa et al. 2013). Considering that lactotroph cells represent the main phenotype in adult female rat pituitaries that express ER $\alpha$ and that GH3 cells have been employed as a prolactinoma model, we compare the ER $\alpha$ expression in GH3 vs normal pituitary cells. The analysis of mER $\alpha$ expression by western blot and immunofluorescence, revelled an increased level of this receptor in tumour cells compared to normal pituitary cells. The involvement of $\mathrm{mER} \alpha$ in the rapid pro-apoptotic action of $\mathrm{E} 2$ in normal pituitary cells has been previously demonstrated (Zarate et al. 2012). In contrast, in pituitary tumour GH3B6/ F10 cells, high levels of mER $\alpha$ mediated rapid signalling responses to oestrogens, which culminated in functional changes such as prolactin release, cell proliferation, apoptosis and changes in cell shape (Jeng et al. 2009, Jeng \& Watson 2011). However, these studies in both normal and pituitary tumour cell did not reveal the 
contribution of palmitoylation to ER $\alpha$ translocation to the plasma membrane. In the present investigation, we detected palmitoylated ER $\alpha$ in normal and GH3 pituitary tumour cells for the first time and demonstrated that E2 stimulated ER $\alpha$ expression in the plasma membrane, which was reverted by the palmitoylation inhibitor. Thus, palmitoylation (a reversible posttranscriptional modification) should be considered to be more than just a simple membrane association of soluble proteins. In fact, the palmitoylation status of several proteins has also been linked to their activation and the regulation of the traffic and function of both the nuclear/cytoplasmic and the membrane receptor pool (Fukata \& Fukata 2010).

In addition to full-length mER, we detected an ER $\alpha$ palmitoylated variant at around $50 \mathrm{kDa}$ in the membrane fraction of pituitary tumour cells. In agreement with this, other authors have reported that, as well as full-length 66-kDa ER $\alpha$, truncated forms of this receptor were present in various organs, produced by alternate ER mRNA splicing or specific post-translational processing, often outside the nucleus. In agreement, a $46-\mathrm{kDa}$ truncated variant has been shown to be preferentially palmitoylated and enriched in the cell membranes of endothelial, osteoblast and breast cancer cells (Denger et al. 2001, Marquez \& Pietras 2001, Li et al. 2003), and palmitoylation inhibitors were able to block ER-46 membrane localisation (Acconcia et al. 2005). Moreover, variants of lower molecular weights ( $\sim 39 \mathrm{kDa}$ and $\sim 22 \mathrm{kDa}$ ) were detected in the membrane fraction of anterior pituitary cells (Zarate et al. 2012) and breast cancer cells, suggesting that these ER $\alpha$ variants may be considered as a target of palmitoylation and result in their localisation in the plasma membrane (Li et al. 2003, Wang et al. 2006).

Palmitoyl-acyltransferase isoform expression and localisation is tissue specific (Ohno et al. 2006), with at least a dozen of the 23 human DHHC genes having been implicated in tumour growth (Yeste-Velasco et al. 2015). DHHC7 and DHHC21 are the proteins responsible for the palmitoylation of the sex steroid oestrogen, progesterone and androgen receptors. DHHC-7 and -21 knockdown studies have shown that PATs are required for endogenous ER palmitoylation, membrane trafficking and rapid signal transduction in cancer cells (Pedram et al. 2012). In the present study, we observed greater Dhhc7 and Dhhc21 mRNA expression in tumour cells than in normal pituitary cells, which may be associated with the proliferative behaviour of GH3 cells. It has been reported that the Dhhc21 gene is significantly overexpressed in human breast cancer compared with normal breast epithelium. It is possible that alterations in the steroid receptor PAT

(C) 2019 Society for Endocrinology Published by Bioscientifica Ltd.
Printed in Great Britain abundance or function contribute to increased ER at the plasma membrane in some situations (Pedram et al. 2012), thereby making the DHHC-7 and -21 proteins attractive novel targets to selectively inhibit membrane sex steroid receptor localisation and function in pituitary tumours.

Although s-acylation is known to be a major regulator of localisation of cellular protein and pathways, there is still little information about how the dynamics of this process is regulated. It has also been reported that palmitoylation regulation may occur via a regulatory mechanism occurring at the mRNA level of the DHHC enzymes (Chai et al. 2013). In this study, E2 treatment for $3 \mathrm{~h}$ reduced both $D h h c 7$ and Dhhc21 mRNA expression, whereas at $30 \mathrm{~min}$ the plasma membrane ER $\alpha$ pool and the interaction ER $\alpha /$ caveolin were increased. The current knowledge of oestrogen molecular action includes the ability of the E2-ER complex both to induce gene transcription (Smith \& O'Malley 2004) and to evoke the membrane-starting activation of specific rapid phosphorylation cascades (ERK/MAPK) (Yang et al. 2004). Both these processes are integrated and influence the cellular response to oestrogen, thus highlighting the ER regulation at genomic and nongenomic levels. The fast action/membrane of E2 ( $30 \mathrm{~min})$ was not in line with that observed after sustained stimulation of E2 for $3 \mathrm{~h}$, which downregulated the mRNA levels of Dhhc7 and Dhhc21, probably as a compensatory mechanism to regulate the ER $\alpha$ pool at the plasma membrane. These results are in agreement those of an investigation that demonstrated that E2 stimulation for 1 to $4 \mathrm{~h}$ decreased by $60 \%$ the $[3 \mathrm{H}]$-palmitate incorporated into ER $\alpha$ in HeLa cells, suggesting that ER $\alpha$ palmitoylation is negatively modulated by E2 (Acconcia et al. 2005).

The relationship between ER $\alpha$ and caveolin appears to be important for determining E2 effects on different cell types, with it having been demonstrated that caveolin-1 is an essential for joining ER $\alpha$ to the cell membrane and that this process is facilitated by prior ER palmitoylation (Pedram et al. 2007). Our results revealed that the ER $\alpha /$ caveolin-1 interaction increased after E2 stimulus in normal as well as in GH3 pituitary tumour cells. Concurring with our data, an ER $\alpha /$ caveolin-1 interaction was demonstrated in enriched $\mathrm{mER} \alpha \mathrm{GH} / \mathrm{B} 6 / \mathrm{F} 10$ pituitary tumour cells (Watson et al. 2012). In addition, it has been reported that, as E2 is highly concentrated in isolated caveolae, it readily engages ER $\alpha$ bound to caveolin-1, which serves as a scaffold for membrane-localised signalling molecules (Peffer et al. 2014). Therefore, caveolin may be a fundamental scaffolding protein whose activation maximises membrane hormone effects and leads to specific biological consequences. This idea is supported 
by caveolin knockdown rats as they, showed a reduction in membrane ER $\alpha$ functions, thereby suggesting that trafficking of ER $\alpha$ to the plasma membrane is mediated by caveolin (Christensen \& Micevych 2012). It has also been demonstrated that caveolin-1 protein downregulation leads to ER $\alpha$ signalling deregulation in mammary epithelia (Wang et al. 2011). We observed that the ERo/caveolin-1 association was palmitoylation dependent, as indicated by the decrease in this association after palmitoylation inhibition. A non-palmitoylable ER $\alpha$-Cys477Ala mutant was unable to localise at the plasma membrane, interact with caveolin-1 or generate E2-induced rapid membranestarting signal pathways to regulate cell proliferation (Acconcia et al. 2005). Moreover, it has been demonstrated that $\mathrm{ER} \alpha$ rapid de-palmitoylation and decoupling the ER $\alpha$ action mechanisms impair the activation of the ERK/MAPK and PI3K/AKT signal transduction pathways (Totta et al. 2004, Levin 2005). These reports are in agreement with our results, where it was observed that pre-incubation with 2BP in GH3 tumoural cells decreased the ER $\alpha$ and caveolin-1 interaction, as well as ERK1/2 phosphorylation, suggesting that palmitoylation is necessary for a mediated $\mathrm{E} 2$ effect.

Several members of the MAP kinase signalling pathway, including Src, Shc and ERKs, are clustered in caveolaespecialised membrane invaginations that are enriched in the caveolin-1 scaffolding protein and compartmentalise signal transduction (Okamoto et al. 1998). ER $\alpha$ activation may trigger cell proliferation mediated by ERK (Jeng et al. 2009, Watson et al. 2010, 2012), with the MEK/ERK1/2 pathway being involved in the pathogenesis of several types of tumours including pituitary adenomas (Vlotides et al. 2008, Ebbesen et al. 2016). It has been reported that the inhibition of ERK1/2 signalling reduced cell viability in rat tumour cells after exposure to a general antagonist of ER (Gao et al. 2017). Here, we observed that the oestrogen antagonist and the palmitoylation inhibitor prevented the activation of ERK1/2 and resulted in a decrease in ER $\alpha$ expression levels in the plasma membrane as well as in cell pituitary proliferation, indicating that rapid E2-induced signals require ER localisation at the plasma membrane. Pedram et al. reported that knockdown of DHHC7 or 21 significantly impaired the ability of E2 to stimulate ERK in breast cancer cells (Pedram et al. 2012). In addition, the expression of ERo without a palmitoylated site interfered with endogenous ER function and inhibited E2-induced ERK activation, cyclin D1 production, cdk4 activity and G1/S progression, suggesting that the inhibition of $\mathrm{mER} \alpha$ expression and its association with the modulation of ERK activity could be put forward as an important therapeutic intervention in breast cancer (Razandi et al. 2003).
It is generally accepted that oestrogens act as potent mitogens through $\mathrm{ER} \alpha$, exerting a sustained, dose-dependent trophic stimulus on anterior pituitary proliferation (Nolan \& Levy 2009). In our study, in primary pituitary cells with a basal proliferation of $2.6 \%$, E2 treatment was unable to modify this mitotic rate. In contrast, in pituitary tumour cells, which exhibited a high basal proliferative activity, E2 stimulation triggered an increase in BrdU uptake with a significant contribution of $m E R \alpha$. Furthermore, palmitoylation inhibition induced a significant decrease in cell proliferation, which was consistent with previous reports showing that mER $\alpha$ contributes, together with the nuclear ER $\alpha$ pool, to the induction of tumour cell proliferation (Razandi et al. 2003). In addition, significantly increased ER $\alpha$ localisation in the plasma membrane has been associated with aggressive breast cancer behaviour or resistance to endocrine therapy (Yang et al. 2004, Fan et al. 2007).

Moreover, these result indicated that oestrogens were able to trigger a proliferative response in the pituitary tumour cell, associated with high levels of ER $\alpha$ and the activation of ERK1/2 signalling (Watson et al. 2008, Jeng et al. 2009). In breast cancer cells, E2-ERo-induced cell transition through $\mathrm{G} 1$ to the $\mathrm{S}$ phase of the cell cycle, which significantly blocked by $2 \mathrm{BP}$ or by inhibitors of MEK, suggesting that membrane localisation of palmitoylated ER $\alpha$ leads to a signal transduction that contributes to cell cycle progression (Pedram et al. 2007). Additionally, the ERK/MAPK and PI3K/AKT pathways, activated by the E2-ERo complex, cooperatively promote the G1/S transition (Marino et al. 2002, Acconcia et al. 2005). In our study, we observed that the palmitoylation inhibitor induced a partial reversion in the tumour proliferation by E2 in a pERK1/2-dependent and pAKT-independent manner.

The differences in the proliferation effect observed between normal and pituitary tumour cells under E2 treatment may be explained by the high ER $\alpha$ expression in tumour cells compared to normal cells, as well as by the undetectable subtype RE $\beta$ expression in GH3 pituitary tumour cells as was previously reported in our laboratory. In addition, we determined the specific role of ER $\beta$ in the E2 proliferative effect in normal, hyperplastic and pituitary tumour cells, with this hormone being able to increase pituitary cell proliferation only in cells with a high ER $\alpha / \beta$ ratio, showing that ER $\beta$ exerts an inhibitory role on the mitogenic activity of pituitary cells (Perez et al. 2015). The reason that different cellular phenotypes can respond to the same hormone in a different manner may be due to the diverse expression patterns of ER $\alpha$ and ER $\beta$ (McDonnell \& Norris 2002). 
In summary, our results showed that E2 modulated ER $\alpha$ palmitoylation, enhancing the mER $\alpha$ pool and consequently activating the ERK pathway, thereby contributing to pituitary tumour cell proliferation. These findings suggest that $\mathrm{mER} \alpha$ could be related to the proliferative behaviour of prolactinoma and be a possible marker of pituitary tumour growth.

\section{Declaration of interest}

The authors declare that there is no conflict of interest that could be perceived as prejudicing the impartiality of the research reported.

\section{Funding}

This work was supported by the Agencia Nacional de Promoción Científica y Tecnológica, Fondo Nacional de Ciencia y Tecnología (ANPCyT-FONCYTPICT 2014-2555), Consejo Nacional de Investigaciones Científicas y Técnicas (CONICET- PIP-Res \#154/2014) and Secretaría de Ciencia y Tecnología de la Universidad Nacional de Córdoba (SECyT-UNC Res \# 313/2016).

\section{Author contribution statement}

The authors would like to make the following declarations about their contributions: $L d V S, J P P$ and $A$ I T conceived and designed the experiments. L d VS, J P P, S C, J P N, F P and P P performed the experiments. $L d V S$, J P P, S C, J P N and F P analysed the data. L d V S, J P P, A D P, J V-T, $S \mathrm{G}$ and $\mathrm{A} I \mathrm{~T}$ prepared the manuscript.

\section{Acknowledgements}

The authors wish to thank Dr Carolina Leimgruber, Lucia Artino, E E Nestor Boetto and Marcos Mirón for their excellent technical assistance. They would also like to thank native speaker Dr Paul Hobson for revising the English of the manuscript.

\section{References}

Acconcia F, Bocedi A, Ascenzi P \& Marino M 2003 Does palmitoylation target estrogen receptors to plasma membrane caveolae? IUBMB Life 55 33-35. (https://doi.org/10.1080/1521654031000081256)

Acconcia F, Ascenzi P, Bocedi A, Spisni E, Tomasi V, Trentalance A, Visca P \& Marino M 2005 Palmitoylation-dependent estrogen receptor alpha membrane localization: regulation by 17beta-estradiol. Molecular Biology of the Cell 16 231-237. (https://doi.org/10.1091/mbc.e04-07-0547)

Boockfor FR, Hoeffler JP \& Frawley LS 1985 Cultures of GH3 cells are functionally heterogeneous: thyrotropin-releasing hormone, estradiol and cortisol cause reciprocal shifts in the proportions of growth hormone and prolactin secretors. Endocrinology 117 418-420. (https:// doi.org/10.1210/endo-117-1-418)

Chai S, Cambronne XA, Eichhorn SW \& Goodman RH 2013 MicroRNA-134 activity in somatostatin interneurons regulates H-Ras localization by repressing the palmitoylation enzyme, DHHC9. PNAS 110 17898-17903. (https://doi.org/10.1073/pnas.1317528110)

Chao W, Xuexin Z, Jun S, Ming C, Hua J, Li G, Tan C \& Xu W 2014 Effects of resveratrol on cell growth and prolactin synthesis in $\mathrm{GH} 3$ cells. Experimental and Therapeutic Medicine 7 923-928. (https://doi org/10.3892/etm.2014.1544)

Christensen A \& Micevych P 2012 CAV1 siRNA reduces membrane estrogen receptor-alpha levels and attenuates sexual receptivity. Endocrinology 153 3872-3877. (https://doi.org/10.1210/en.2012-1312)

Denger S, Reid G, Kos M, Flouriot G, Parsch D, Brand H, Korach KS, Sonntag-Buck V \& Gannon F 2001 ERalpha gene expression in human primary osteoblasts: evidence for the expression of two receptor proteins. Molecular Endocrinology 15 2064-2077. (https://doi. org/10.1210/mend.15.12.0741)

De Paul AL, Gutierrez S, Sabatino ME, Mukdsi JH, Palmeri CM, Soaje M, Petiti JP \& Torres AI 2011 Epidermal growth factor induces a sexually dimorphic proliferative response of lactotroph cells through protein kinase C-ERK1/2-Pit-1 in vitro. Experimental Physiology 96 226-239. (https://doi.org/10.1113/expphysiol.2010.054502)

Ebbesen SH, Scaltriti M, Bialucha CU, Morse N, Kastenhuber ER, Wen HY, Dow LE, Baselga J \& Lowe SW 2016 Pten loss promotes MAPK pathway dependency in HER2/neu breast carcinomas. PNAS 113 3030-3035. (https://doi.org/10.1073/pnas.1523693113)

Fan P, Wang J, Santen RJ \& Yue W 2007 Long-term treatment with tamoxifen facilitates translocation of estrogen receptor alpha out of the nucleus and enhances its interaction with EGFR in MCF-7 breast cancer cells. Cancer Research 67 1352-1360. (https://doi. org/10.1158/0008-5472.CAN-06-1020)

Ferraris J, Zarate S, Jaita G, Boutillon F, Bernadet M, Auffret J, Seilicovich A, Binart N, Goffin V \& Pisera D 2014 Prolactin induces apoptosis of lactotropes in female rodents. PLOS ONE 9 e97383. (https://doi.org/10.1371/journal.pone.0097383)

Friend KE, Chiou YK, Lopes MB, Laws ER Jr, Hughes KM \& Shupnik MA 1994 Estrogen receptor expression in human pituitary: correlation with immunohistochemistry in normal tissue, and immunohistochemistry and morphology in macroadenomas. Journal of Clinical Endocrinology and Metabolism 78 1497-1504. (https://doi. org/10.1210/jcem.78.6.7515390)

Fukata Y \& Fukata M 2010 Protein palmitoylation in neuronal development and synaptic plasticity. Nature Reviews Neuroscience 11 161-175. (https://doi.org/10.1038/nrn2788)

Gao H, Xue Y, Cao L, Liu Q, Liu C, Shan X, Wang H, Gu Y \& Zhang Y 2017 ESR1 and its antagonist fulvestrant in pituitary adenomas. Molecular and Cellular Endocrinology 443 32-41. (https://doi. org/10.1016/j.mce.2016.12.029)

Gutierrez S, De Paul AL, Petiti JP, Sosa LdV, Palmeri CM, Soaje M, Orgnero EM \& Torres AI 2008 Estradiol interacts with insulin through membrane receptors to induce an antimitogenic effect on lactotroph cells. Steroids 73 515-527. (https://doi.org/10.1016/j. steroids.2008.01.002)

Gutierrez S, Sosa L, Petiti JP, Mukdsi JH, Mascanfroni ID, Pellizas CG, De Paul AL, Cambiasso MJ \& Torres AI 2012 17beta-Estradiol stimulates the translocation of endogenous estrogen receptor alpha at the plasma membrane of normal anterior pituitary cells. Molecular and Cellular Endocrinology 355 169-179. (https://doi.org/10.1016/j. mce.2012.02.008)

Heaney AP, Fernando M \& Melmed S 2002 Functional role of estrogen in pituitary tumor pathogenesis. Journal of Clinical Investigation 109 277-283. (https://doi.org/10.1172/JCI0214264)

Jeng YJ \& Watson CS 2011 Combinations of physiologic estrogens with xenoestrogens alter ERK phosphorylation profiles in rat pituitary cells. Environmental Health Perspectives 119 104-112. (https://doi. org/10.1289/ehp.1002512)

Jeng YJ, Kochukov MY \& Watson CS 2009 Membrane estrogen receptoralpha-mediated nongenomic actions of phytoestrogens in GH3/B6/ F10 pituitary tumor cells. Journal of Molecular Signaling 4 2. (https:// doi.org/10.1186/1750-2187-4-2)

Le Lay S \& Kurzchalia TV 2005 Getting rid of caveolins: phenotypes of caveolin-deficient animals. Biochimica et Biophysica Acta 1746 322-333. (https://doi.org/10.1016/j.bbamcr.2005.06.001) 
Levin ER 2005 Integration of the extranuclear and nuclear actions of estrogen. Molecular Endocrinology 19 1951-1959. (https://doi. org/10.1210/me.2004-0390)

Li L, Haynes MP \& Bender JR 2003 Plasma membrane localization and function of the estrogen receptor alpha variant (ER46) in human endothelial cells. PNAS 100 4807-4812. (https://doi.org/10.1073/ pnas.0831079100)

Marino M, Acconcia F, Bresciani F, Weisz A \& Trentalance A 2002 Distinct nongenomic signal transduction pathways controlled by 17betaestradiol regulate DNA synthesis and cyclin $\mathrm{D}(1)$ gene transcription in HepG2 cells. Molecular Biology of the Cell 13 3720-3729. (https://doi. org/10.1091/mbc.e02-03-0153)

Marino M, Ascenzi P \& Acconcia F 2006 S-palmitoylation modulates estrogen receptor alpha localization and functions. Steroids $\mathbf{7 1}$ 298-303. (https://doi.org/10.1016/j.steroids.2005.09.011)

Marquez DC \& Pietras RJ 2001 Membrane-associated binding sites for estrogen contribute to growth regulation of human breast cancer cells. Oncogene 20 5420-5430. (https://doi.org/10.1038/ sj.onc.1204729)

McDonnell DP \& Norris JD 2002 Connections and regulation of the human estrogen receptor. Science 296 1642-1644. (https://doi. org/10.1126/science.1071884)

Meitzen J, Luoma JI, Boulware MI, Hedges VL, Peterson BM, Tuomela K, Britson KA \& Mermelstein PG 2013 Palmitoylation of estrogen receptors is essential for neuronal membrane signaling. Endocrinology 154 4293-4304. (https://doi.org/10.1210/en.2013-1172)

Mitchner NA, Garlick C \& Ben-Jonathan N 1998 Cellular distribution and gene regulation of estrogen receptors alpha and beta in the rat pituitary gland. Endocrinology 139 3976-3983. (https://doi. org/10.1210/endo.139.9.6181)

Morrill GA, Kostellow AB \& Gupta RK 2015 Transmembrane helices in 'classical' nuclear reproductive steroid receptors: a perspective. Nuclear Receptor Signaling 13 e003. (https://doi.org/10.1621/nrs.13003)

Nolan LA \& Levy A 2009 Prolonged oestrogen treatment does not correlate with a sustained increase in anterior pituitary mitotic index in ovariectomized Wistar rats. Journal of Endocrinology 200 301-309. (https://doi.org/10.1677/JOE-08-0474)

Ohno Y, Kihara A, Sano T \& Igarashi Y 2006 Intracellular localization and tissue-specific distribution of human and yeast DHHC cysteinerich domain-containing proteins. Biochimica et Biophysica Acta 1761 474-483. (https://doi.org/10.1016/j.bbalip.2006.03.010)

Okamoto T, Schlegel A, Scherer PE \& Lisanti MP 1998 Caveolins, a family of scaffolding proteins for organizing 'preassembled signaling complexes' at the plasma membrane. Journal of Biological Chemistry 273 5419-5422. (https://doi.org/10.1074/jbc.273.10.5419)

Oorschot VM, Sztal TE, Bryson-Richardson RJ \& Ramm G 2014 Immuno correlative light and electron microscopy on Tokuyasu cryosections. Methods in Cell Biology 124 241-258. (https://doi.org/10.1016/B978-012-801075-4.00011-2

Park JH, Lee MY \& Han HJ 2009 A potential role for caveolin-1 in estradiol-17beta-induced proliferation of mouse embryonic stem cells: involvement of Src, PI3K/Akt, and MAPKs pathways. International Journal of Biochemistry and Cell Biology 41 659-665. (https://doi. org/10.1016/j.biocel.2008.07.010)

Pedram A, Razandi M, Aitkenhead M, Hughes CC \& Levin ER 2002 Integration of the non-genomic and genomic actions of estrogen. Membrane-initiated signaling by steroid to transcription and cell biology. Journal of Biological Chemistry 277 50768-50775. (https://doi. org/10.1074/jbc.M210106200)

Pedram A, Razandi M, Sainson RC, Kim JK, Hughes CC \& Levin ER 2007 A conserved mechanism for steroid receptor translocation to the plasma membrane. Journal of Biological Chemistry 282 22278-22288. (https://doi.org/10.1074/jbc.M611877200)

Pedram A, Razandi M, Deschenes RJ \& Levin ER 2012 DHHC-7 and -21 are palmitoylacyltransferases for sex steroid receptors. Molecular
Biology of the Cell 23 188-199. (https://doi.org/10.1091/mbc.e11-070638)

Peffer ME, Chandran UR, Luthra S, Volonte D, Galbiati F, Garabedian MJ, Monaghan AP \& DeFranco DB 2014 Caveolin-1 regulates genomic action of the glucocorticoid receptor in neural stem cells. Molecular and Cellular Biology 34 2611-2623. (https://doi.org/10.1128/ MCB.01121-13)

Perez PA, Petiti JP, Wagner IA, Sabatino ME, Sasso CV, De Paul AL, Torres AI \& Gutierrez S 2015 Inhibitory role of ERbeta on anterior pituitary cell proliferation by controlling the expression of proteins related to cell cycle progression. Molecular and Cellular Endocrinology 415 100-113. (https://doi.org/10.1016/j.mce.2015.08.009)

Petiti JP, Gutierrez S, De Paul AL, Andreoli V, Palmeri CM, Sosa Ldel V, Bocco JL \& Torres AI 2010 GH3B6 pituitary tumor cell proliferation is mediated by PKCalpha and PKCepsilon via ERK 1/2-dependent pathway. Cellular Physiology and Biochemistry 26 135-146. (https://doi. org/10.1159/000320519)

Petiti JP, del V Sosa L, Sabatino ME, Vaca AM, Gutierrez S, De Paul AL \& Torres AI 2015 Involvement of MEK/ERK1/2 and PI3K/Akt pathways in the refractory behavior of GH3B6 pituitary tumor cells to the inhibitory effect of TGFbeta1. Endocrinology 156 534-547. (https:// doi.org/10.1210/en.2014-1070)

Razandi M, Oh P, Pedram A, Schnitzer J \& Levin ER 2002 ERs associate with and regulate the production of caveolin: implications for signaling and cellular actions. Molecular Endocrinology 16 100-115. (https://doi.org/10.1210/mend.16.1.0757)

Razandi M, Alton G, Pedram A, Ghonshani S, Webb P \& Levin ER 2003 Identification of a structural determinant necessary for the localization and function of estrogen receptor alpha at the plasma membrane. Molecular and Cellular Biology 23 1633-1646. (https://doi. org/10.1128/MCB.23.5.1633-1646.2003)

Smith CL \& O'Malley BW 2004 Coregulator function: a key to understanding tissue specificity of selective receptor modulators. Endocrine Reviews 25 45-71. (https://doi.org/10.1210/er.2003-0023)

Sosa LdV, Gutierrez S, Petiti JP, Vaca AM, De Paul AL \& Torres AI 2013 Cooperative effect of $\mathrm{E}(2)$ and FGF2 on lactotroph proliferation triggered by signaling initiated at the plasma membrane. American Journal of Physiology-Endocrinology and Metabolism 305 E41-E49. (https://doi.org/10.1152/ajpendo.00027.2013)

Spady TJ, McComb RD \& Shull JD 1999 Estrogen action in the regulation of cell proliferation, cell survival, and tumorigenesis in the rat anterior pituitary gland. Endocrine 11 217-233. (https://doi. org/10.1385/ENDO:11:3:217)

Totta P, Acconcia F, Leone S, Cardillo I \& Marino M 2004 Mechanisms of naringenin-induced apoptotic cascade in cancer cells: involvement of estrogen receptor alpha and beta signalling. IUBMB Life 56 491-499. (https://doi.org/10.1080/15216540400010792)

Totta P, Gionfra F, Busonero C \& Acconcia F 2015 Modulation of 17betaestradiol signaling on cellular proliferation by caveolin-2. Journal of Cellular Physiology 231 1219-1225. (https://doi.org/10.1002/jcp.25218)

Ueda K \& Karas RH 2013 Emerging evidence of the importance of rapid, non-nuclear estrogen receptor signaling in the cardiovascular system. Steroids 78 589-596. (https://doi.org/10.1016/j.steroids.2012.12.006)

Vlotides G, Siegel E, Donangelo I, Gutman S, Ren SG \& Melmed S 2008 Rat prolactinoma cell growth regulation by epidermal growth factor receptor ligands. Cancer Research 68 6377-6386. (https://doi. org/10.1158/0008-5472.CAN-08-0508)

Wan J, Roth AF, Bailey AO \& Davis NG 2007 Palmitoylated proteins: purification and identification. Nature Protocols 2 1573-1584. (https:// doi.org/10.1038/nprot.2007.225)

Wang Z, Zhang X, Shen P, Loggie BW, Chang Y \& Deuel TF 2006 A variant of estrogen receptor-\{alpha\}, hER-\{alpha\}36: transduction of estrogen- and antiestrogen-dependent membrane-initiated mitogenic signaling. PNAS 103 9063-9068. (https://doi.org/10.1073/ pnas.0603339103) https://joe.bioscientifica.com

https://doi.org/10.1530/JOE-18-0418
(C) 2019 Society for Endocrinology Published by Bioscientifica Ltd. Printed in Great Britain 
Wang X, Feng S, Zhang H, Wang Y, Cui Y, Wang Z, Liu J \& Zou W 2011 RNA inference-mediated caveolin-1 down-regulation decrease estrogen receptor alpha (ERalpha) signaling in human mammary epithelial cells. Molecular Biology Reports 38 761-768. (https://doi. org/10.1007/s11033-010-0164-5)

Watson CS, Bulayeva NN, Wozniak AL \& Finnerty CC 2005 Signaling from the membrane via membrane estrogen receptor-alpha: estrogens, xenoestrogens, and phytoestrogens. Steroids 70 364-371. (https://doi.org/10.1016/j.steroids.2005.03.002)

Watson CS, Jeng YJ \& Kochukov MY 2008 Nongenomic actions of estradiol compared with estrone and estriol in pituitary tumor cell signaling and proliferation. FASEB Journal 22 3328-3336. (https://doi. org/10.1096/fj.08-107672)

Watson CS, Jeng YJ \& Kochukov MY 2010 Nongenomic signaling pathways of estrogen toxicity. Toxicological Sciences 115 1-11. (https:// doi.org/10.1093/toxsci/kfp288)
Watson CS, Jeng YJ, Hu G, Wozniak A, Bulayeva N \& Guptarak J 2012 Estrogen- and xenoestrogen-induced ERK signaling in pituitary tumor cells involves estrogen receptor-alpha interactions with $\mathrm{G}$ proteinalphai and caveolin I. Steroids 77 424-432. (https://doi.org/10.1016/j. steroids.2011.12.025)

Yang Z, Barnes CJ \& Kumar R 2004 Human epidermal growth factor receptor 2 status modulates subcellular localization of and interaction with estrogen receptor alpha in breast cancer cells. Clinical Cancer Research 10 3621-3628. (https://doi.org/10.1158/1078-0432.CCR-0740-3)

Yeste-Velasco M, Linder ME \& Lu YJ 2015 Protein S-palmitoylation and cancer. Biochimica et Biophysica Acta 1856 107-120. (https://doi. org/10.1016/j.bbcan.2015.06.004)

Zarate S, Jaita G, Ferraris J, Eijo G, Magri ML, Pisera D \& Seilicovich A 2012 Estrogens induce expression of membrane-associated estrogen receptor alpha isoforms in lactotropes. PLoS ONE 7 e41299. (https:// doi.org/10.1371/journal.pone.0041299)

Received in final form 26 October 2018

Accepted 31 October 2018
(C) 2019 Society for Endocrinology Published by Bioscientifica Ltd. 